\section{Cranial MRI Findings in Predicting the Severity of Hypoxic-Ischemic Encephalopathy in Term Neonates}

\author{
Term Yenidoğanlarda Hipoksik-iskemik Ensefalopati \\ Siddetini Öngörmede Kraniyal MRG Bulguları
}

\section{Mehmet Coşkun ${ }^{\odot}$ Oğuz Han Kalkanlı ๑ Rüya Çolak $\odot$ Senem Alkan Özdemir ๑ Tülin Gökmen Yıldırım • Şebnem Çalkavur $\odot$ Fazıl Gelal ๑}

\section{ABSTRACT}

Objective: The aim of this study is to compare magnetic resonance imaging (MRI) findings with severity of hypoxic-ischemic encephalopathy (HIE) in term neonates.

Methods: Sixty-three newborns with HIE in whom cranial MRIs were performed within the first 3 weeks of life between 2016 and 2020 were included in the study. Severity of HIE was graded using Sarnat \& Sarnat staging. In statistical analysis, Stage 1 was considered as mild, Stage 2 or 3 as severe HIE. The signal intensities of perirolandic cortex, posterior limb of internal capsule (PLIC), globus pallidus, and cerebrospinal tract on T1- weighted imaging (T1WI), and of perirolandic cortex, PLIC, ventrolateral thalamus, lateral edge of putamen and tegmentum on T2WI, and brain diffusion weighted imaging (DWI) findings were evaluated with consensus by two radiologists blinded to clinical findings. Gestational age, birth weight and MRI signal intensities were compared with HIE groups using $t$ test, and Fisher-Exact test.

Results: There were 31 and 32 infants with mild and severe HIE, respectively. Gestational age and birth weight were not different between mild and severe HIE groups. The number of cases with abnormal signals in PLIC and globus pallidus on T1WI, and PLIC on T2WI were significantly higher in severe HIE $(p=0.022, p=0.008$, and $p=0.032$, respectively). The presence of signal abnormality in other regions and DWI were not significantly different between HIE groups.

Conclusion: Cranial MRI may play a remarkable role in determining pattern and severity of HIE. Signal abnormality in PLIC and globus pallidus may suggest severe HIE in term neonates.

Keywords: Neuroimaging, magnetic resonance imaging, diffusion magnetic resonance imaging, hypoxicIschemic encephalopathy, neonate

öz

Amaç: Bu çalışmanın amacı, term yenidoğanlarda manyetik rezonans görüntüleme (MRG) bulgularıla hipoksik-iskemik ensefalopati (HiE) şiddetinin karşılaştırılmasıdır.

Yöntem: 2016 ile 2020 arasında HIE tanılı ve doğumdan sonraki 3 hafta içerisinde kraniyal MRG yapılan 63 term yenidoğanı kapsamaktadır. HiE, Sarnat \& Sarnat sınıflaması ile evrelenmiştir. Evre 1 hafif HiE, evre 2 veya 3 şiddetli HiE olarak kabul edildi. T1 ağırlıklı görüntülemede (AG) perirolandik korteks, internal kapsül arka bacağı (iKAB), globus pallidus, serebrospinal tractus sinyali, T2AG'de perirolandik korteks, iKAB, ventrolateral talamus, putamen lateral kenarı ve tegmentum sinyali ve difüzyon kısıtlaması klinik bilgiden yoksun 2 radyolog tarafindan konsensüs ile değerlendirildi. Hafif ve şiddetli HiE hasta grubu, gebelik haftası ve doğum ağırlığı açısından t testi, MRG sinyali Fisher-Exact testi kullanılarak karşıllaştıııldı.

Bulgular: Otuz-bir yenidoğanda hafif, 32 yenidoğanda şiddetli HiE vardı. Hafif ile şiddetli HiE hasta grubu karşılaştırıldığında, gebelik haftası ve doğum ağırlığı açısından fark yoktu. T1A'da iKAB ve globus pallidusta, T2A'da IKAB'da anormal sinyal, şiddetli HiE'de daha fazlaydı (sırasıyla $p=0,022, p=0,008$ ve $p=0,032$ ). Diğer bölgelerin T1 ve T2A sinyali ve difüzyon kısıtıılığı farklı değildi.

Sonuç: MRG, HIE şiddetini ve paternini tespit etmede önemli bir rol oynar. Term yenidoğanda kraniyal MRG'de, IKAB'da T1 ve T2A'da ve globus pallidusta T1A'da anormal sinyal, şiddetli HiE'yi akla getirmelidir.

Anahtar kelimeler: Nörogörüntüleme, manyetik rezonans görüntüleme, difüzyon ağırlıklı görüntüleme, hipoksik-iskemik ensefalopati, yenidoğan
Received: 20.11 .2020

Accepted: 09.12 .2020

Published Online: 30.04 .2021

Cite as: Coşkun M, Kalkanlı OH, Çolak R, et al. Cranial MRI findings in predicting the severity of hypoxicischemic encephalopathy in term neonates. izmir $\mathrm{Dr}$. Behçet Uz Çocuk Hast. Dergisi. 2021;11(1):15-22.

Mehmet Coşkun

S.B.Ü. Dr. Behçet Uz Çocuk Hastalıkları ve Cerrahisi Ĕgitim ve Araştırma Hastanesi, Radyoloji Bölümü, İzmir, Türkiye

dr.mehmetcoskun@hotmail.com ORCID: 0000-0003-4339-898X

O.H. Kalkanlı 0000-0003-1965-1420 R. Çolak 0000-0002-8732-7932

S. Alkan Özdemir 0000-0003-0474-7120 T. Gökmen Yıldııım 0000-0001-5951-2631

Ş. Çalkavur 0000-0002-3820-2690

S.B.Ü. Dr. Behçet Uz Çocuk Hastalıkları ve Cerrahisi Eğitim ve Araştırma Hastanesi, Yenidoğan Kliniği, izmir, Türkiye

F. Gelal 0000-0003-1263-0918 Izmir Katip Çelebi Üniversitesi Atatürk Eğitim ve Araştırma Hastanesi, Radyoloji Anabilim Dalı, Izmir, Türkiye 


\section{INTRODUCTION}

Hypoxic-ischemic encephalopathy (HIE), in other words perinatal asphyxia, is one of leading causes of neonatal mortality and morbidity worldwide (1). Hypoxic or ischemic processes may result in brain injury which can be reversible or irreversible. Approximately $40 \%$ of survivors have neurological disorders such as cerebral palsy, mental retardation, epilepsy despite hypothermia treatment ${ }^{(2,3)}$.

In hypoxic-ischemic neonates, the first 6 hours of life is critical to start therapeutic hypothermia. Hypothermia, as a neuroprotective treatment, reduces neonatal mortality and morbidity, and improves long-term outcomes (2,4,5). Despite hypothermia treatment, neonates with severe and prolonged HIE still develop adverse outcomes ${ }^{(3,6)}$. Severity of HIE can be determined by Sarnat \& Sarnat clinical staging in early period ${ }^{(7)}$. The Bayley Scales of Infant and Toddler Development-III (Bayley-III) is used in infants between 18 and 24 months to determine long- term results. However, MRI is the ideal technique to detect perinatally acquired cerebral lesions and evaluate therapeutic efficacy of hypothermia ${ }^{(4)}$.

In a healthy term infant, perirolandic cortex, posterior limb of internal capsule (PLIC), cerebrospinal tractus, and globus pallidus demonstrate high signal intensities on T1- weighed images (T1WI). Perirolandic cortex, PLIC, ventrolateral thalamus, tegmentum and lateral edge of putamen have low signal intensities on $\mathrm{T} 2 \mathrm{WI}{ }^{(5)}$. Absence of increased T1 signal intensity of PLIC may predict severe outcome ${ }^{(8)}$. Widespread signal abnormalities were also significantly associated with poor neurological outcome ${ }^{(9)}$. We evaluated MRI signal intensities of these specific regions one by one.

The main goal of this study is to compare MRI findings with severity of HIE in term neonates.

\section{MATERIAL and METHOD}

\section{Study population}

This was a retrospective study approved by the ethics committee. It included hospitalized term ( $\geq 35$ weeks of gestational age) neonates, who were clinically diagnosed with HIE, and had cranial MRI within the first 3 weeks after birth between 2016 and 2020. The cases who had any contraindication for MRI, could not undergo MRI due to unstable clinical conditions or death, underwent MRI when older than 3 weeks of age ( $n: 3)$, had non-diagnostic MRIs due to prominent artifacts ( $n: 2)$ and preterm infants were excluded from the study.

\section{Categorization of HIE}

Severity of HIE was graded using Sarnat \& Sarnat scale ${ }^{(7)}$. Accordingly, stages of HIE were divided into 3 levels using characteristic features as alertness, muscle tone, posture, reflexes, pupils, seizures, electroencephalography (EEG) findings, and duration of HIE. Stage 1 infants are hyperalert, have normal or increased muscle tone, normal posture, hyperactive tendon reflexes, mydriatic pupils without seizures and normal EEG with HIE lasting less than 24 hours. Stage 2 infants are lethargic, hypotonic, miotic, and had weak reflexes. Conversely, Stage 3 infants are in coma, and characterized with flaccid muscle tone, decerebrate posture, absence of tendon reflexes, anisocoric pupils, decerebrate seizures, and burst suppression or isoelectric activity in EEG persisting for weeks. Stage 1 was considered as mild, Stages 2 and 3 as severe HIE in statistical analysis.

\section{Acquisition and evaluation of the MRIs}

All patients were scanned with a 1.5 Tesla $(T)$ scanner (Toshiba, Japan). Cranial MRIs included axial and sagittal T1W fast spin echo (FSE), axial T2W FSE, axial and coronal T2W fluid attenuated inversion recovery (FLAIR), axial flow-sensitive black blood imaging susceptible to hemorrhage, and axial diffusion weighted imaging with b:0 and b:1000 sec/ $\mathrm{mm} 2$ and apparent diffusion coefficient map. The acquisition parameters are given in Table 1.

In the first session, the images were evaluated independently by two radiologists blind to any clinical information. Interreader agreement was determined. In the second session, discrepancies were resolved, and definitive results were achieved by consensus. 
Table 1. Acquisition parameters of cranial MRI.

\begin{tabular}{lccccc}
\hline & $\begin{array}{c}\text { Field-of- } \\
\text { view } \\
\text { (mm) }\end{array}$ & $\begin{array}{c}\text { Matrix } \\
\text { (frequency } \\
\text { phase) }\end{array}$ & $\begin{array}{c}\text { Slice } \\
\text { thickness } \\
\text { (mm) }\end{array}$ & $\begin{array}{c}\text { TR } \\
\text { (msn) }\end{array}$ & $\begin{array}{c}\text { TE } \\
(\mathbf{m s n})\end{array}$ \\
\hline Axial T1WI FSE & $190 \times 190$ & $304 \times 160$ & 2.5 & 773 & 12 \\
Axial T2WI FSE & $190 \times 152$ & $352 \times 160$ & 2.5 & 6206 & 105 \\
Axial T2WI FLAIR & $190 \times 152$ & $256 \times 160$ & 2.5 & 7900 & 105 \\
Coronal T2WI FLAIR & $170 \times 170$ & $320 \times 160$ & 3 & 6898 & 105 \\
Sagittal T1WI FSE & $210 \times 168$ & $256 \times 160$ & 3 & 432 & 8 \\
Axial GRE* & $180 \times 144$ & $256 \times 160$ & 1 & 29 & 20 \\
DWI** & $280 \times 124$ & $192 \times 128$ & 4 & 5600 & 120
\end{tabular}

TR: repetition time; TE: echo time; T1WI: T1 weighted imaging; T2WI: T2 weighted imaging; FSE: fast spin echo; FLAIR: Fluid attenuated inversion recovery; GRE: gradient echo; DWI: diffusion weighted imaging.

*Flow-sensitive black blood imaging susceptible to hemorrhage. **Diffusion weighted imaging with b:0 and b:1000 $\mathrm{sec} / \mathrm{mm}^{2}$ in axial plane.

The signal intensities of perirolandic cortex, PLIC, globus pallidus, and cerebrospinal tract on T1WI, and of perirolandic cortex, PLIC, ventrolateral thalamus, lateral edge of putamen and tegmentum on $\mathrm{T} 2 \mathrm{WI}$ were evaluated. The signal intensities of these regions were recorded as normal or pathologic based on the predefined criteria ${ }^{(5)}$. DWI and ADC images were evaluated for the presence or absence of diffusion restriction.

\section{Statistical analysis}

Data were analyzed with SPSS version $20\left(\right.$ IBM $^{\circledR}$, Armonk, NY, USA). Interreader agreement was determined using Kappa statistics, and classified as follows: 0.01-0.20, slight; 0.21-0.40, fair; 0.41-0.60, moderate; 0.61-0.80, substantial; and 0.81-0.99, almost perfect interreader agreement.

In patient groups with mild and severe HIE, gestational ages and birth weights were compared using $\mathrm{t}$ test, and MRI signals using Fisher Exact test. $\mathrm{P}<0.05$ was considered statistically significant.

\section{RESULTS}

The median age of 63 cases ( 33 girls and 30 boys) included in this study was 7 days $( \pm 3.2)$. Median gestational age and birth weight were 39 weeks and 3340 grams, respectively (Table 2). Twenty-eight infants were born by normal vaginal delivery, and 35 infants by cesarean section.
Table 2. Demographic results of the cohort .

\begin{tabular}{lcc}
\hline & Mean \pm SD & Minimum-maximum \\
\hline Age (days) & $6.8 \pm 3.2$ & $1-21$ \\
Gestational age (weeks) & $38.8 \pm 1.8$ & $35-42$ \\
Birth weight (grams) & $3268 \pm 506$ & $1300-4230$ \\
& \#Girl & \#oy \\
Gender & 33 & 30 \\
& \#Normal & $\# \mathrm{C} / \mathrm{S}$ \\
Type of birth & 28 & 35 \\
& & \\
SD: standard deviation; $C / S:$ cesarean section.
\end{tabular}

According to Sarnat \& Sarnat classification, the neonates had Stage $1(n=31), 2(n=21)$, and $3(n=11)$ HIE. Consequently, 31 newborns had mild, and 32 had severe HIE.

Interreader agreement was almost perfect (Kappa $=0.867)$. Thirty-three (52.4\%) infants had totally normal MRI findings (Figure 1). Twenty-one of 33 (63.6\%) infants had mild, while 12 (36.4\%) infants had severe HIE. On the other hand, 30 (47.6\%) infants had at least a pathology in their MRIs. On T1WI, the signal was abnormal in perirolandic cortex in 10 , internal capsule in 17, globus pallidus in 16, and cerebrospinal tract in 12 infants. On T2WI, the signal was abnormal in perirolandic cortex in 7, internal capsule in 14, thalamus in 12, putamen in 7, and tegmentum in 9 infants (Figure 2). On DWI, diffusion restriction was not seen in 38 out of 63 patients (Figure 3 ).

There was no significant difference between mild and severe HIE groups in terms of gestational age and birth weight ( $p=0.183$ and $p=0.625$, respectively). PLIC signal on T1WI was abnormal in $12.9 \%$ of infants with mild HIE, and in $40.7 \%$ of infants with severe HIE with a statistically significant intergroup difference ( $p=0.022)$. Globus pallidus signals detected on T1WI was abnormal in $9.7 \%$ of infants with mild, and $40.7 \%$ of infants with severe HIE with a statistically significant intergroup difference $(p=0.008)$. PLIC signal on $\mathrm{T} 2 \mathrm{WI}$ was more frequently abnormal in infants with severe HIE $(p=0.032)$. The signal intensities of other regions were not statistically different between mild and severe HIE groups (Table 3 ). Diffusion restriction was noted in $29 \%$ of infants with mild, and $50 \%$ of infants with severe HIE without any statistically significant intergroup difference $(p=0.123)$. 

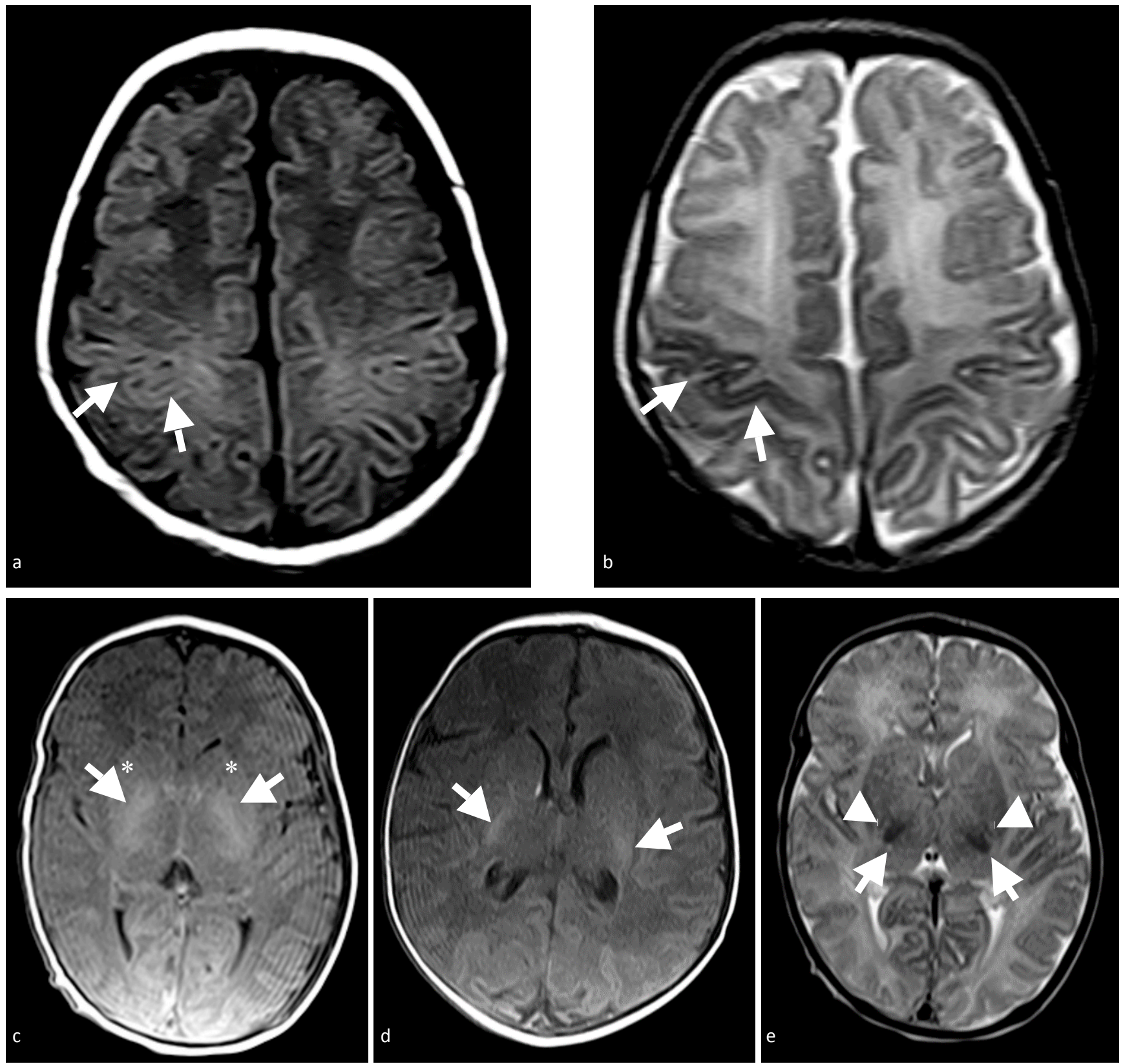

Figure 1. Normal signals of the specific regions in different term neonates with mild HIE. Perirolandic cortex is a) hyperintense in T1, and b) hypointense in T2 weighed imaging (WI) (arrows). c) Globus pallidus (arrows) is brighter than putamen (asterisks), and d) posterior limb of internal capsule (PLIC) is hyperintense (arrows) in T1WI. e) PLIC (arrowheads) is shown as a thin dark bant, and ventrolateral thalamus (arrows) was hypointense in T2WI.

\section{DISCUSSION}

In this study, we found that signals of PLIC on T1WI and T2WI and globus pallidus on T1WI were more frequently abnormal in term infants with severe HIE than in term infants with mild HIE. All infants included in the study were in their first 3 weeks of life.

Two basic MRI patterns are defined in term infants with HIE: 1. Peripheral/watershed pattern, 2. Central/basal ganglion-thalamic pattern ${ }^{(5,6,10,11)}$. Mild to moderate HIE causes peripheral injury which 

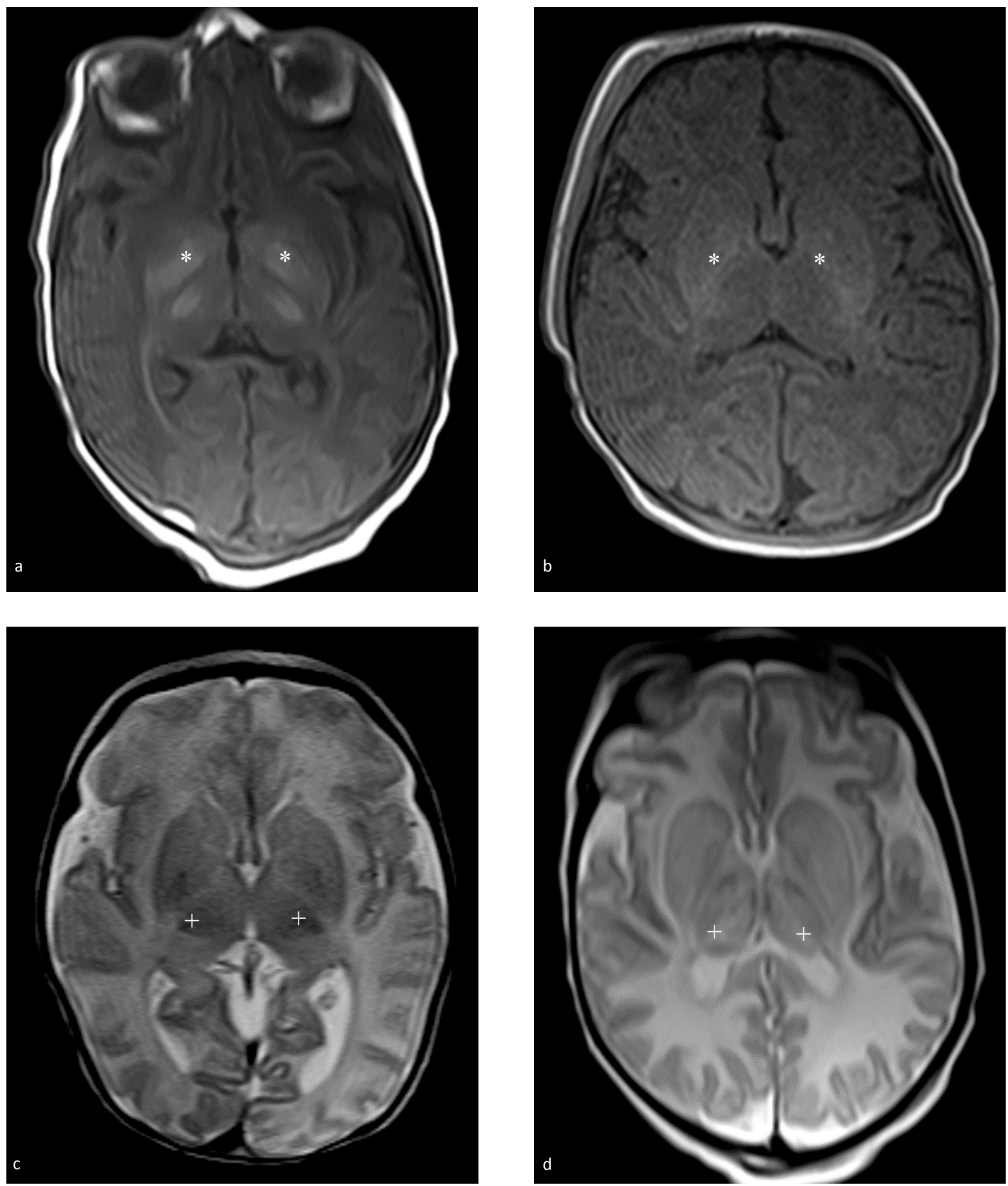

Figure 2. Abnormal signals of the specific regions in different term neonates with severe HIE. a) Case 1 is presented with absent hyperintense posterior limb of internal capsule (PLIC) despite having hyperintense globus pallidus (asterisks) in T1 weighted imaging (WI). b) Case $\mathbf{2}$ has abnormal globus pallidus without hyperintensity in T1WI. c) Case $\mathbf{3}$ has absent hypointense PLIC sign despite having hypointense ventrolateral thalamus (plus signs) in T2WI. d) Case 4 has neither hypointense PLIC nor hypointense thalamus in T2WI. 

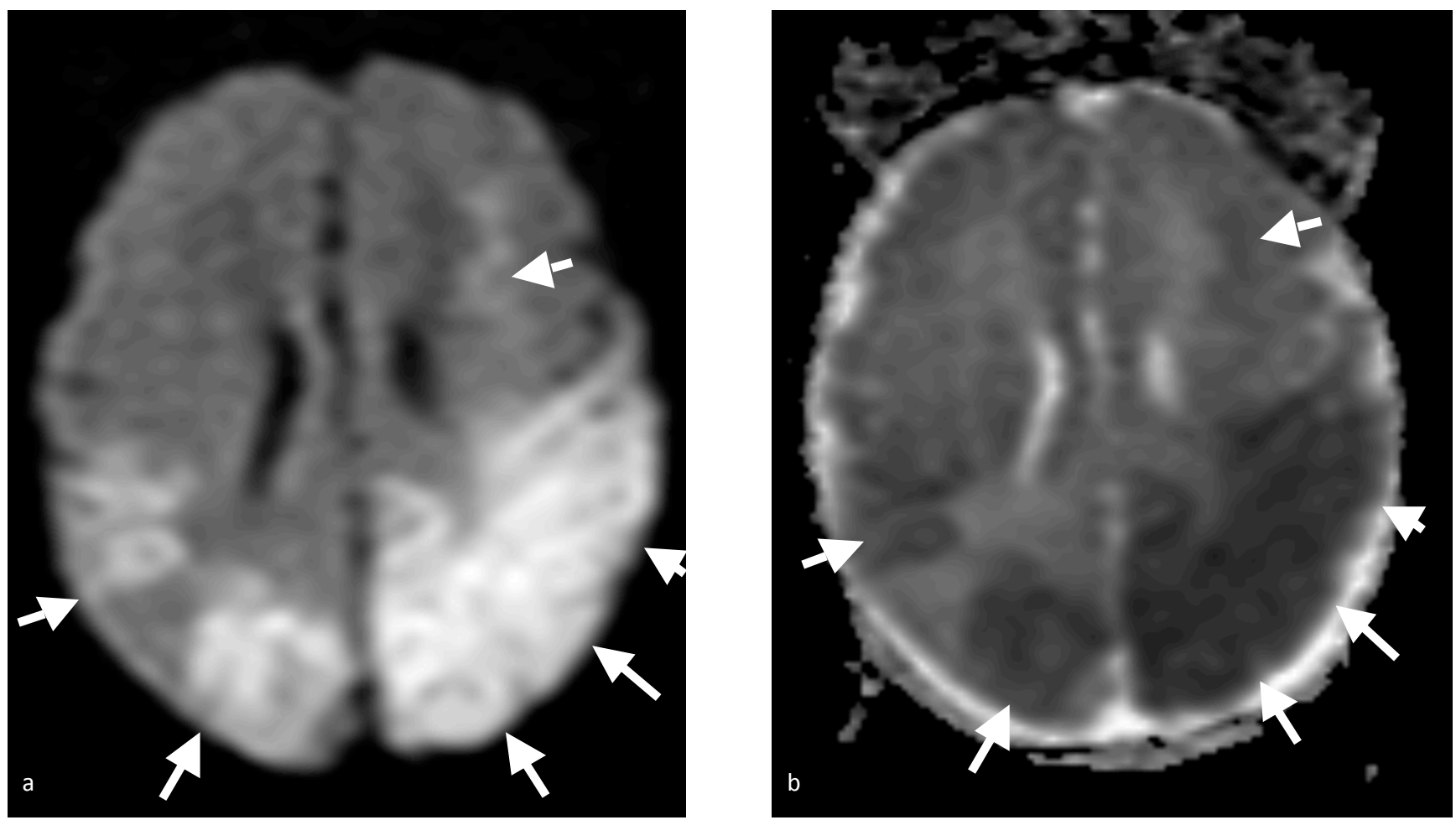

Figure 3. Diffusion weighted imaging with a) b:1000 sec/mm and b) apparent diffusion coefficient map (ADC) is showing extensive acute diffusion restriction affecting left frontal deep white matter and almost diffuse bilateral parietal lobe (arrows).

Table 3. Comparison of MRI findings of the infants with mild and severe HIE.

\begin{tabular}{|c|c|c|c|}
\hline & $\begin{array}{l}\text { "Mild HIE } \\
\text { n:31 (\%) }\end{array}$ & $\begin{array}{c}\text { \#Severe HIE } \\
\text { n:32 (\%) }\end{array}$ & $P$ value \\
\hline Gestational age (weeks) (mean \pm SD) & $39 \pm 1.7$ & $38.5 \pm 1.8$ & 0.183 \\
\hline Birth weight (grams) (mean \pm SD) & $3297 \pm 569$ & $3239 \pm 444$ & 0.625 \\
\hline $\begin{array}{l}\text { Number of cases with normal } \\
\text { MRIs }\end{array}$ & 21 & 12 & \\
\hline $\begin{array}{l}\text { Number of cases with } \\
\text { abnormal MRIs } \\
\text { Abnormal signals }\end{array}$ & 10 & 20 & \\
\hline Perirolandic cortex on T1WI & $4(12.9)$ & $6(18.8)$ & 0.732 \\
\hline PLIC on T1WI & $4(12.9)$ & $13(40.7)$ & 0.022 \\
\hline Globus pallidus on T1WI & $3(9.7)$ & $13(40.7)$ & 0.008 \\
\hline tractus on $\mathrm{T} 1 \mathrm{WI}$ & $3(9.7)$ & $9(28.1)$ & 0.107 \\
\hline Perirolandic cortex on T2WI & $3(9.7)$ & $4(12.5)$ & 1 \\
\hline PLIC on T2WI & $3(9.7)$ & $11(34.4)$ & 0.032 \\
\hline Thalamus on $\mathrm{T} 2 \mathrm{WI}$ & $3(9.7)$ & $9(28.1)$ & 0.107 \\
\hline Putamen on T2WI & $2(6.5)$ & $5(15.6)$ & 0.426 \\
\hline Tegmentum on T2WI & $3(9.7)$ & $6(18.8)$ & 0.474 \\
\hline Diffusion restriction on DWI & $9(29)$ & $16(50)$ & 0.123 \\
\hline
\end{tabular}

HIE: hypoxic ischemic encephalopathy; SD: standard deviation; T1WI: T1 weighted imaging; PLIC: posterior limb of internal capsule; T2WI: T2 weighted imaging; DWI: diffusion weighted imaging. involves peripheral cortex and adjacent subcortical white matter in the parasagittal border zones. Severe HIE results in central injury affecting basal ganglia, thalamus, hippocampus, and brain stem ${ }^{(6)}$. Miller et al reported that the central pattern was associated with more intensive resuscitation at birth, more severe encephalopathy, and seizure. It was related with impaired cognitive and motor sequelae at 30 months, as well ${ }^{12)}$. In our study, abnormal globus pallidus signal on T1WI was associated with severe HIE. This result supports the assumption that central pattern may have a poor prognosis.

Internal capsule carries critically important fibers including corticospinal tractus with major motor fibers and corticothalamic connections ${ }^{(13)}$. These fibers are myelinated in term infants and easily visible with high signal intensity on $\mathrm{T} 1 \mathrm{WI}$ and low signal intensity on $\mathrm{T} 2 \mathrm{WI}{ }^{(5,6,13)}$. Abnormal signal in PLIC is a strong predictor of abnormal motor outcome ${ }^{(8,9,14)}$. Okereafor et al. ${ }^{(14)}$ reported that $86 \%$ of term infants who died or developed cerebral palsy had abnormal signals in PLIC. Liauw et al. ${ }^{(15)}$ investigated signals of 19 different 
brain regions on T1WI and found that lower signal ratio of PLIC/posterolateral putamen was correlated with adverse outcome. Positive predictivity of PLIC/ putamen ratio was higher than that of Sarnat \& Sarnat staging (69\% vs 52\%, respectively). In our study, abnormal PLIC signals on $\mathrm{T} 1$ and $\mathrm{T} 2 \mathrm{WI}$ were more frequently associated with severe HIE when compared with mild HIE.

American College of Obstetricians and Gynecologists (ACOG) suggested that early imaging can be obtained within the first 24-96 hours, optimally at 10 days but with an acceptable window between 7-21 days of life ${ }^{(3)}$. DWI is useful in detection of cytotoxic edema even at $24^{\text {th }}$ hour. It is more sensitive than T1W1 or T2WI in the first week. Signal abnormality on DWI usually peaks at 3-5 days of life while early imaging before 5 days may underestimate the injury on T1WI and T2WI. On the other hand, T1WI and T2WI present details about anatomy and myelinization process. These sequences are valuable between 7-14 days of life when signal abnormality begins to normalize on DWI (pseudo-normalization on $10^{\text {th }}-12^{\text {nd }}$ day) ${ }^{(6,11)}$. Additionally, neonatal brain MRI should be optimized with a higher repetition time, compared to adults, for both T1WI (800 msec vs $400 \mathrm{msec}$ ) and T2WI (6500 msec vs $4000 \mathrm{msec}$ ) (16). In our study, MRIs were optimized for neonatal imaging and obtained within 3 weeks complying with ACOG's proposal. Although the purpose of the study was not to make comparisons between DWI and conventional MRI sequences, we realized that abnormal signals were more often seen on DWI than on T1WI or T2WI. In our study, DWI findings were not significantly different between mild and severe HIE groups which may be due to the timing of our DWI acquisitions. DWI evaluation within the first 5 days of life would improve the value of this technique. We evaluated DWI data only for the presence or absence of diffusion restriction; however, detailed evaluation including the location of diffusion abnormality would further improve the benefits of DWI.

Cranial ultrasonography is an option in suspected cases with HIE. It is useful in detection of hydrocephalus, cystic periventricular leukomalacia, and germinal matrix hemorrhage which is a predominant pattern in HIE of premature infants. It has a limited value in the detection of cortical lesions and highly operator dependent ${ }^{(6)}$. CT may be useful in screening for bleeding without need for sedation (17). However, it has several disadvantages including limited contrast resolution, inability to discriminate between gray, and white matter abnormalities, and radiation exposure. Magnetic resonancespectroscopy (MRS) has a potential in early detection of HIE even within first 24 hours after birth in term neonates ${ }^{(5)}$. Elevated lactate-choline ratio was related with poor neurological outcome ${ }^{(18)}$. However, MRS is prone to artifact formation, may require sedation, and has limited availability ${ }^{(6,19)}$. We did not use these methods due to the limitations described above.

This study had several limitations. Firstly, it was a retrospective study with a small sample size. These types of studies have the potential of bias. We evaluated the MRIs by two radiologists blinded to clinical findings to minimize bias. Secondly, some infants were too small that resulted in low signal-tonoise ratio. Motion-free acquisition is also difficult in infants. Although non-diagnostic MRIs were excluded $(n: 2)$ and MRIs were optimized for infants, the image quality was still poor in $1.5 \mathrm{~T}$ for some neonates. The $3 \mathrm{~T}$ scanners might provide a better image quality. Thirdly, the findings of MRIs were compared with Sarnat \& Sarnat clinical staging. Further clinical outcomes could not be estimated based on these results due to lack of long-term neurological assessment.

In conclusion, cranial MRI demonstrates involvement and spread of brain injury in HIE. Abnormal signals detected in PLIC and globus pallidus in conventional MRI may suggest severe HIE. These retrospective findings should be supported with prospective studies.

Ethics Committee Approval: S.B.Ü. Izmir Dr. Behçet Uz Pediatric Diseases and Surgery Training and Research Hospital Ethics Committee approval was obtained (19.11.2020/209).

Conflict of Interest: Nothing to disclosure.

Funding: Used no funding resource.

Informed Consent: Obtained. 


\section{REFERENCES}

1. Agut T, León M, Rebollo M, Muchart J, Arca G, Garcia-Alix A. Early identification of brain injury in infants with hypoxic ischemic encephalopathy at high risk for severe impairments: accuracy of MRI performed in the first days of life. BMC Pediatr. 2014;14:177. Epub 2014/07/10. PubMed PMID: 25005267 ; PubMed Central PMCID: PMCPMC4113122. https://doi.org/10.1186/1471-2431-14-177

2. Jacobs SE, Berg M, Hunt R, Tarnow-Mordi WO, Inder TE, Davis PG. Cooling for newborns with hypoxic ischaemic encephalopathy. Cochrane Database Syst Rev. 2013;2013(1):Cd003311. Epub 2013/02/27. PubMed PMID: 23440789; PubMed Central PMCID: PMCPMC7003568 controlled trials, the Infant Cooling Evaluation (ICE) trial. https://doi.org/10.1002/14651858.CD003311.

3. Executive summary: Neonatal encephalopathy and neurologic outcome, second edition. Report of the American College of Obstetricians and Gynecologists' Task Force on Neonatal Encephalopathy. Obstet Gynecol. 2014;123(4):896901. Epub 2014/05/03. https://doi.org/10.1097/01.AOG.0000445580.65983.d2

4. Rutherford M, Ramenghi LA, Edwards AD, Brocklehurst $P$, Halliday $\mathrm{H}$, Levene $\mathrm{M}$, et al. Assessment of brain tissue injury after moderate hypothermia in neonates with hypoxicischaemic encephalopathy: a nested substudy of a randomised controlled trial. Lancet Neurol. 2010;9(1):39-45. Epub 2009/11/10. PubMed PMID: 19896902; PubMed Central PMCID: PMCPMC2795146.

https://doi.org/10.1016/S1474-4422(09)70295-9

5. Ghei SK, Zan E, Nathan JE, Choudhri A, Tekes A, Huisman TA, et al. MR imaging of hypoxic-ischemic injury in term neonates: pearls and pitfalls. Radiographics. 2014;34(4):104761. Epub 2014/07/16. PubMed PMID: 25019441. https://doi.org/10.1148/rg.344130080

6. Varghese B, Xavier R, Manoj VC, Aneesh MK, Priya PS, Kumar $A$, et al. Magnetic resonance imaging spectrum of perinatal hypoxic-ischemic brain injury. Indian J Radiol Imaging. 2016;26(3):316-27. Epub 2016/11/20. PubMed PMID: 27857456; PubMed Central PMCID: PMCPMC5036328. https://doi.org/10.4103/0971-3026.190421

7. Sarnat HB, Sarnat MS. Neonatal encephalopathy following fetal distress. A clinical and electroencephalographic study. Arch Neurol. 1976;33(10):696-705. Epub 1976/10/01. PubMed PMID: 987769. https://doi.org/10.1001/archneur.1976.00500100030012

8. Rutherford MA, Pennock JM, Counsell SJ, Mercuri E, Cowan FM, Dubowitz LM, et al. Abnormal magnetic resonance signal in the internal capsule predicts poor neurodevelopmental outcome in infants with hypoxicischemic encephalopathy. Pediatrics. 1998;102(2 Pt 1):323-8. Epub 1998/08/01. PubMed PMID: 9685433.

https://doi.org/10.1542/peds.102.2.323

9. Trivedi SB, Vesoulis ZA, Rao R, Liao SM, Shimony JS, McKinstry
$\mathrm{RC}$, et al. A validated clinical MRI injury scoring system in neonatal hypoxic-ischemic encephalopathy. Pediatr Radiol. 2017;47(11):1491-9. Epub 2017/06/18. PubMed PMID: 28623417; PubMed Central PMCID: PMCPMC6219383. https://doi.org/10.1007/s00247-017-3893-y

10. Heinz ER, Provenzale JM. Imaging findings in neonatal hypoxia: a practical review. AJR Am J Roentgenol. 2009;192(1):41-7. Epub 2008/12/23. PubMed PMID: 19098177.

https://doi.org/10.2214/AJR.08.1321

11. Bano S, Chaudhary V, Garga UC. Neonatal Hypoxic-ischemic Encephalopathy: A Radiological Review. J Pediatr Neurosci. 2017;12(1):1-6. Epub 2017/05/30. PubMed PMID: 28553370; PubMed Central PMCID: PMCPMC5437770. https://doi.org/10.4103/1817-1745.205646

12. Miller SP, Ramaswamy V, Michelson D, Barkovich AJ, Holshouser B, Wycliffe $\mathrm{N}$, et al. Patterns of brain injury in term neonatal encephalopathy. J Pediatr. 2005;146(4):45360. Epub 2005/04/07. PubMed PMID: 15812446. https://doi.org/10.1016/j.jpeds.2004.12.026

13. Cowan FM, de Vries LS. The internal capsule in neonatal imaging. Semin Fetal Neonatal Med. 2005;10(5):461-74. Epub 2005/07/09. PubMed PMID: 16002354. https://doi.org/10.1016/j.siny.2005.05.007

14. Okereafor A, Allsop J, Counsell SJ, Fitzpatrick J, Azzopardi D, Rutherford MA, et al. Patterns of brain injury in neonates exposed to perinatal sentinel events. Pediatrics. 2008;121(5):906-14. Epub 2008/05/03. PubMed PMID: 18450893. https://doi.org/10.1542/peds.2007-0770

15. Liauw L, van der Grond J, van den Berg-Huysmans AA, Laan $L A$, van Buchem MA, van Wezel-Meijler $G$. Is there a way to predict outcome in (near) term neonates with hypoxicischemic encephalopathy based on MR imaging? AJNR Am J Neuroradiol. 2008;29(9):1789-94. Epub 2008/07/05. PubMed PMID: 18599574 https://doi.org/10.3174/ajnr.A1188

16. Shroff MM, Soares-Fernandes JP, Whyte $H$, Raybaud C. MR imaging for diagnostic evaluation of encephalopathy in the newborn. Radiographics. 2010;30(3):763-80. Epub 2010/05/14. PubMed PMID: 20462993. https://doi.org/10.1148/rg.303095126

17. Barkovich AJ. Pediatric Neuroimaging, 4th ed. American Journal of Neuroradiology. 2007;28(1):190-290.

18. Zarifi MK, Astrakas LG, Poussaint TY, Plessis Ad A, Zurakowski D, Tzika AA. Prediction of adverse outcome with cerebral lactate level and apparent diffusion coefficient in infants with perinatal asphyxia. Radiology. 2002;225(3):859-70. Epub 2002/12/04. PubMed PMID: 12461272. https://doi.org/10.1148/radiol.2253011797

19. Barkovich AJ, Miller SP, Bartha A, Newton N, Hamrick SE, Mukherjee $P$, et al. MR imaging, MR spectroscopy, and diffusion tensor imaging of sequential studies in neonates withencephalopathy. AJNRAm J Neuroradiol. 2006;27(3):53347. Epub 2006/03/23. PubMed PMID: 16551990. 